\title{
Study of Population Structure of Microalgae in Sanandaj Dam-Iran
}

\author{
Fatemeh Sadat Tahami* and Alireza Keyhan Sani \\ Caspian Sea Ecology Research Center (CSERC), Iranian Fisheries Science Research Institute (IFSRI), Agricultural Research, Iran
}

*Corresponding author: Fatemeh Sadat Tahami, Caspian Sea Ecology Research Center (CSERC), Iranian Fisheries Science

Research Institute (IFSRI), Agricultural Research, Education and Extension Organization (AREEO), Iran

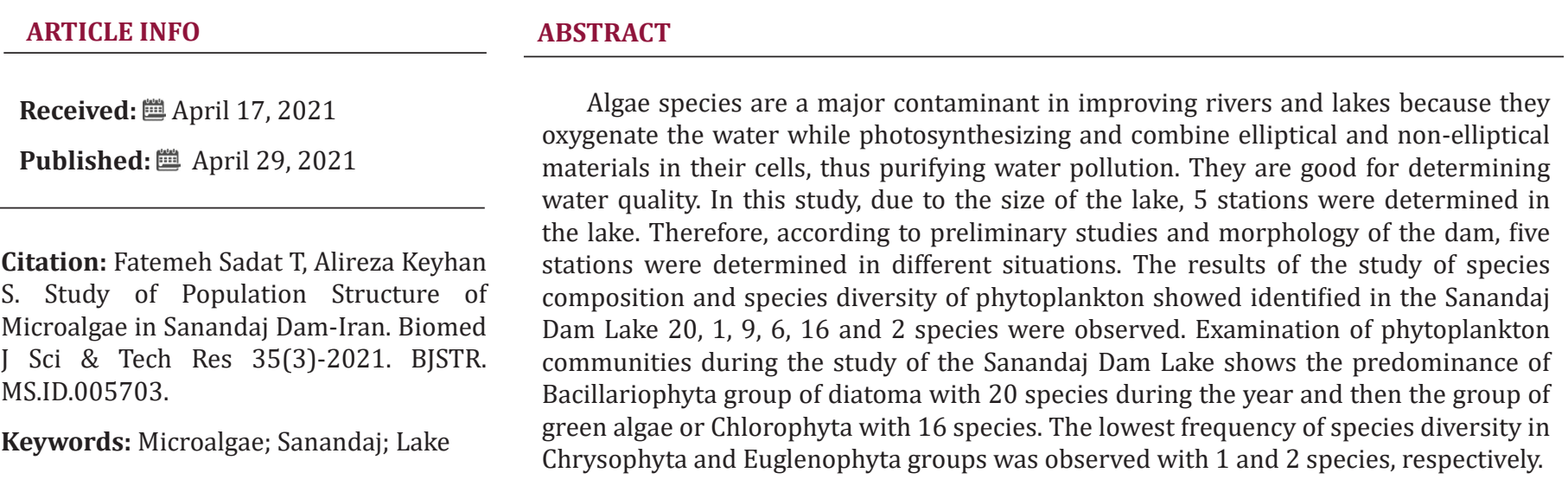

\section{Introduction}

Algae are the basis of primary production in aquatic ecosystems. The onset of food production in a aquatic environment begins with these organisms and with a complex mechanism called photosynthesis. In this process, simple foods are transformed into complex organic compounds and become a single food unit. This food collection will be fed to other aquatic organisms in the next steps (consumption). Algae are very important in aquaculture because they directly affect water properties such as color, odor, taste, dissolved oxygen, and turbidity. Natural food production in breeding ponds is directly related to the growth rate of these small, microscopic plants, so that the higher the algae growth rate, the more natural the production of natural food (algae and non-algae) will be with Latter Njiru, et al., [1] and as the rate of natural food production increases, so does the growth rate of organisms under fish farming and production Anneville, et al. [2].

Rivers have been studied in other countries for a long time, but in Iran they have been young and have been studied in research centers in the country for almost two decreases. They are microalgae and Nitzschia, Naviculla and Diatoms are the most abundant in these ecosystems. Chlorophyta and Cyanophyta

groups had a significant frequency after diatoms Anneville, et al. [2]. In some seasons of the year, due to the increase in nutrients in aquatic ecosystems, the entry of untreated sewage and agricultural effluents, etc. (causes algae blooms such as Cyanophyta (green-blue algae) and excessive accumulation of algae in the water surface causes saturation. Water in made from oxygen, reducing $\mathrm{CO}_{2}$ and thus reducing photosynthesis and nitrogen fixation Rakaj [3]. Preventing photosynthesis ultimately leads to the destruction of algae and then their breakdown by bacteria and the rapid use of oxygen by bacteria leads to a decrease in the oxygen content of the water, which endangers the life of the aquatic life and causes their death Mirzajani, et al. [4].

Other adverse effects include the formation of blooms by greenblue algae and the release of toxins in the water, which in addition to fish can cause disease and death of other aquatic and domestic animals and even endanger human health (Contact or consumption of contaminated water or contaminated fish). About 25 toxic species of this phylum have been reported so far. Of course, in the case of rivers, their origin can be unknown, and the timing of their contact with pollutants and the dam is affected by microalgae conditions 
Moisan, et al. [5]. In the ecological study of aquatic ecosystems, algae are used as determinants of environmental change. Algae have many connections (dependencies) with their surroundings, and environmental factors affecting algae include light, inorganic materials (Nutrition) and so on. There is a strong link between light intensity and the rate of synthesis of substances in algae cells, and high light intensity increases the rate of synthesis of various compounds such as lipids and polysaccharides Richmond [6].

Algae are used in various aquatic ecosystems to assess water quality or water pollution. The compound and microalgae can be used as a complementary indicator of water trophy levels Wan Maznah, et al. [7]. The growth and proliferation of microalgae depends on the dynamics of the water, the amount of light spectrum, and the availability of food and the quality and stability of water resource around the world is important, although these resources are exposed to pollution in the catchment areas of domestic water systems Wan Maznah, et al. [7]. The development of towns and villages along rivers and beaches, and subsequently the proliferation of industrial and agricultural centers, increases the pollution burden caused by waste and water-polluting waste. These pollutants are able to create unpredictable changes in the environment and water resources and endanger the lives of microalgae and other aquatic animals.

\section{Materials and Methods}

Field activity of this research was performed for one year from June 2015 to June 2016 at seasonal sampling intervals. Due to the size of the lake, 5 stations were determined in the lake. Therefore, according to preliminary studies and morphology of the dam, five stations were determined in different situations according to Figure $1 \& 2$ in the whole lake. Also, due to the depth of the station, in stations 4 and 5 (with a depth of 10 meters) only one sample of the surface layer, in station 3 three layers (surface layer, middle layer and 1 meter above the bed) and in two stations 2 and 1 if there is a thermocline, the sampling was performed at five depths as follows: The surface layer of water, layer 1.3 from the depth of the station from the water surface, layer 2.3 from the depth of the station from the surface of the water and one meter above the sediments of the bed were made by other sampling bottle (Maximum volume of 2 layers) (Figure 1). The specimens were immediately recorded in $4 \%$ formalin fixation specimen and station characteristics and time of sampling and transferred in $500 \mathrm{ml}$ glass containers to planktonic laboratory of Caspian Institute of Ecology. In this method, the specimens were kept in the dark for 10 nights in the laboratory to completely precipitate. It was then discharged with a special upperlevel siphon or supernatant that lacked any plankton.

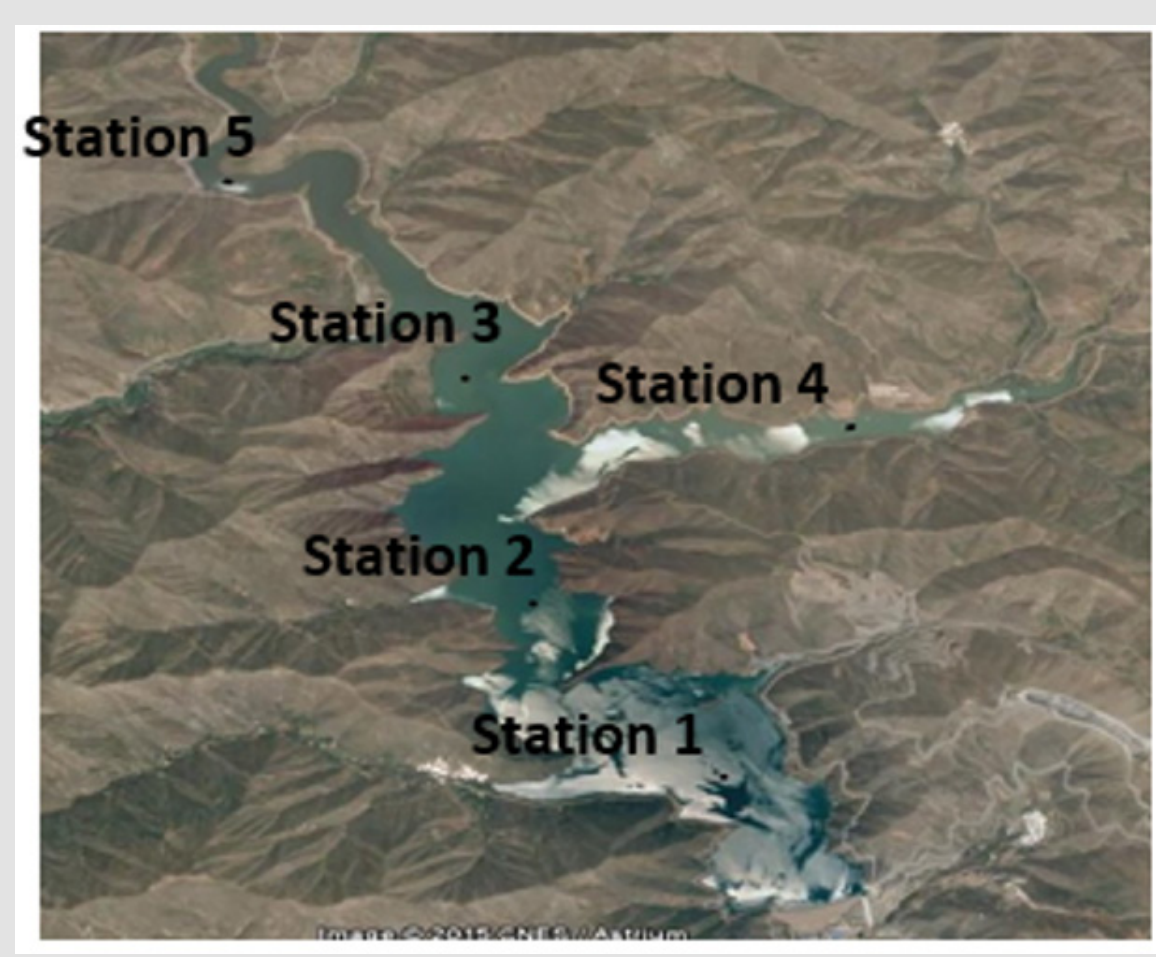

Figure 1: Timeline of the longitudinal survey. 


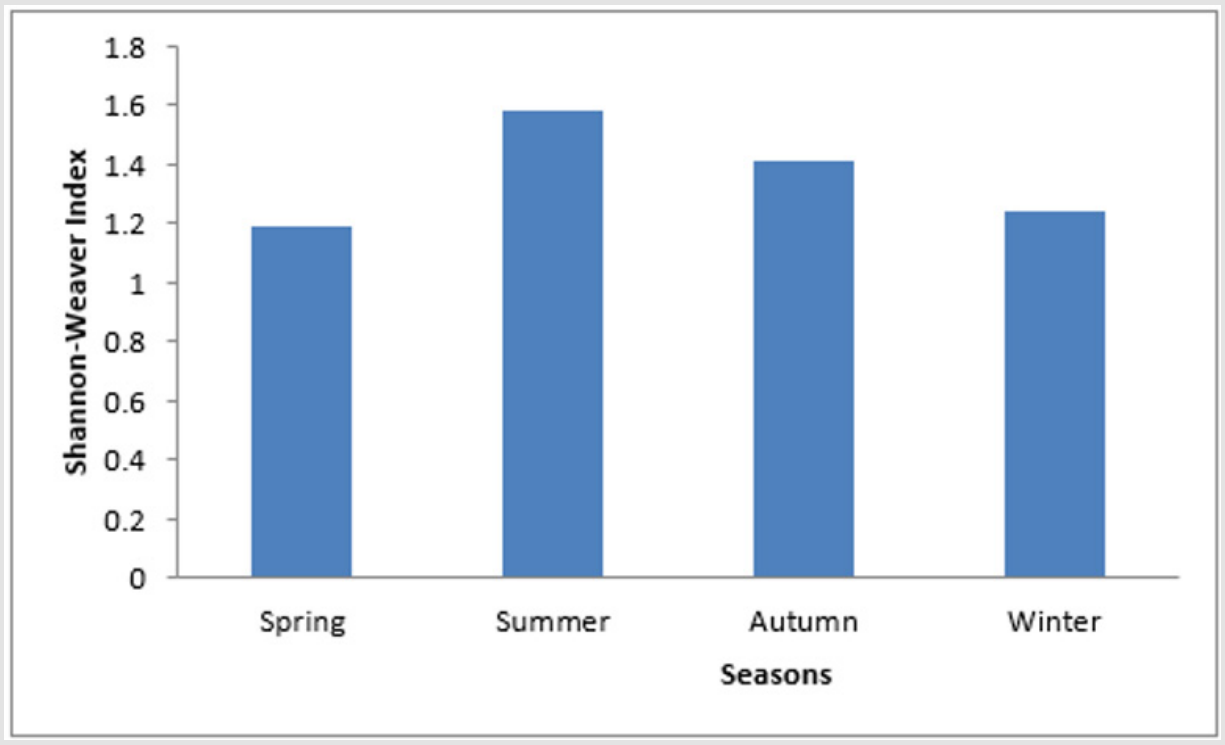

Figure 2: Shannon H' microalgae index in the Sanandaj Dam Lake.

Note: The Shannon index varied in different seasons with the highest in the summer at 1.58 and then in the fall (1.41), winter (1.24) and spring (1.19), respectively.

The remaining samples were centrifuged (Labofuge200) at a speed of $3000 \mathrm{rpm}$ for several minutes to achieve a final volume of 25-30 ml. Samples were counted on linear slides by pipet pistons with volume of $0.1 \mathrm{~cm}^{3}$ (APHA, 2005). The samples were homogenized after centrifugation and stained with a few drops of eosin and then identified and examined under a microscope at 10x, 20x and 40x magnification. At this stage it is a qualitative review and it is important to know their limits only to dilute or concentrate it if it is too high for the quantification phase. After quantitative determination of the samples, after determination of dilution or concentration in the qualitative phase, the sample was precipitated for $24 \mathrm{~h}$ and then, using a pipette, removed $0.1 \mathrm{ml}$ of the sample and stained using eosin. The microscope was identified and the number and then the density per cubic meter were counted (APHA, 2005; Newell and Newell, 1977). Average statistical comparisons of data were calculated by analysis of variance (ANOVA), Multiple and mean comparison test using Shannon-Weaver (Shannon and Weaver. 1963) formula and by the formula:

$$
\begin{aligned}
& H^{\prime}=-\sum P_{i} \operatorname{In} P_{i} \\
& \mathrm{H}^{\prime}=\text { Shannon-Weaver Index (nits per individual) } \\
& \mathrm{Pi}=\text { relative frequency of species }
\end{aligned}
$$

The Palmer Contamination Ratio (Palmer 1968) was used to evaluate water quality.

\section{Results}

The results of the study of species composition and species diversity of microalgae showed identified in the Sanandaj Dam Lake 20, 1, 9, 6, 16 and 2 species were observed. Examination of microalgae communities during the study of the Sanandaj Dam Lake shows the predominance of Bacillariophyta group of diatoma with 20 species during the year and then the group of green algae or Chlorophyta with 16 species. The lowest frequency of species diversity in Chrysophyta and Euglenophyta groups was observed with 1 and 2 species, respectively (Tables 1 \& 2). The species diversity in the Bacillariophyta group was such that in the spring, summer, autumn and winter seasons, 8, 7, 10 and 9 species were observed respectively, whose diversity in the autumn season was higher than other seasons. The Chrysophyta group had only one microalgae representative, which was identified in summer and autumn. The Pyrophyta group also had 6, 6, 1 and 2 species during the spring to winter seasons, respectively, while the Cyanophyta group did not have a representative in the summer and had 2, 5 and 1 species in the spring, autumn and winter seasons. Also, the green plankton group, or Chlorophyta, had 8, 10, 7, and 6 species, respectively, during the spring to winter seasons in the Sanandaj Dam Lake, and the Euglenophyta group was observed with only two species during the summer and autumn seasons (Figure 2) (Table $3)$. 
Table 1: Frequency of presence and absence of microalgae species identified in different seasons in the Sanandaj Dam Lake.

\begin{tabular}{|c|c|c|c|c|c|}
\hline \multicolumn{2}{|c|}{ Microalgae } & \multicolumn{4}{|c|}{ Seasons } \\
\hline Microalgae Phylum & Microalgae Species & Spring & Summer & Autumn & Winter \\
\hline \multirow{20}{*}{ Bacillariophyta } & Actinocyclus paraduxus & + & & + & \\
\hline & Amphora ovalis & + & & & \\
\hline & Amphora sp. & + & & & \\
\hline & Cocconeis placentula & & + & + & \\
\hline & Cyclotella caspica & & & + & \\
\hline & Cyclotella menenghiniana & + & + & + & + \\
\hline & Cymbella ventricosa & & & + & + \\
\hline & Diatoma ochki & & & + & \\
\hline & Navicula cryptocephala & & + & + & + \\
\hline & Navicula sp. & & & & + \\
\hline & Nitzschia acicularis & + & + & & + \\
\hline & Nitzschia sigma & & & & + \\
\hline & Nitzschia parva & & + & + & \\
\hline & Nitzschia sp. & + & & & \\
\hline & Nitzschia tenuirostris & + & & & \\
\hline & Stephanodiscos hantzschii & + & & + & + \\
\hline & Stephanodiscos sp. & & & & + \\
\hline & Thalassionema nitzschoide & & + & & \\
\hline & Thalassiosira inserta & & + & + & \\
\hline & Thalassiosira variabilis & & & & + \\
\hline Total & & 8 & 7 & 10 & 9 \\
\hline Chrysophyta & Dinobryon divergens & & + & + & \\
\hline Total & & & 1 & 1 & \\
\hline \multirow{9}{*}{ Pyrophyta } & Exuviaella cordata & & + & & \\
\hline & Glenodinium penardi & + & + & + & \\
\hline & Glenodinium behningii & & + & & \\
\hline & Goniaulax digitale & + & + & & \\
\hline & Goniaulax minima & & + & & \\
\hline & Goniaulax polyedra & + & & & + \\
\hline & Goniaulax polyedra & + & + & & \\
\hline & Goniaulax spinifera & + & & & \\
\hline & Peridinium latum & + & & & + \\
\hline Total & & 5 & 6 & 1 & 2 \\
\hline \multirow{6}{*}{ Cyanophyta } & Anabaena aphanizomenides & & & + & \\
\hline & chroococcus sp. & & & + & + \\
\hline & Gleoocapsa turgida & + & & + & \\
\hline & Merismopedia minima & & & + & \\
\hline & Oscillatoria limosa & & & + & \\
\hline & Spirulina laxissma & + & & & \\
\hline \multirow[t]{6}{*}{ Total } & & 2 & & 5 & 1 \\
\hline & Ankistrodesmus falcatus & + & + & + & \\
\hline & Binuclearia lauterbornii & & + & & \\
\hline & Celnslrum microporum & & + & & \\
\hline & Chlorellas sp. & + & + & + & + \\
\hline & Closterum monilipherum & + & & + & \\
\hline
\end{tabular}




\begin{tabular}{|c|c|c|c|c|c|}
\hline \multirow{11}{*}{ Chlorophyta } & Coelastrum letrapedia & & + & & \\
\hline & corococcus & & & & + \\
\hline & Hualodiscus sphoerophorus & & + & & \\
\hline & Oocystis borgi & & + & + & \\
\hline & Oocystis solitaria & + & & & + \\
\hline & Pediastrum tetras & + & & & \\
\hline & Scenedesmus quadricauda & + & + & + & + \\
\hline & Schroderia sp. & & & & + \\
\hline & Staurastrum polymorphum & & + & + & \\
\hline & Tetraederon sp. & & + & & \\
\hline & Tetraederon minimum & & & + & + \\
\hline Total & & 8 & 10 & 7 & 6 \\
\hline \multirow{2}{*}{ Euglenophyta } & Euglena acus & & + & & \\
\hline & Trachelomonas planctoniea & & & + & \\
\hline Total & & & 1 & 1 & \\
\hline
\end{tabular}

Table 2: Number of microalgae species identified in different seasons in the Sanandaj Dam Lake.

\begin{tabular}{|c|c|c|c|c|c|c|c|}
\hline Total & Euglenophyta & Chlorophyta & Cyanophyta & Pyrophyta & Chrysophyta & Bacillariophyta & $\begin{array}{c}\text { Phylum of Microalgae } \\
\text { Seasons }\end{array}$ \\
\hline 24 & & 8 & 2 & 6 & & 8 & Spring \\
\hline 25 & 1 & 10 & & 6 & 1 & 1 & Summer \\
\hline 25 & 1 & 7 & 5 & 1 & 1 & 10 & Autumn \\
\hline 18 & & 6 & 1 & 2 & & 9 & Winter \\
\hline 92 & 2 & 31 & 8 & 15 & 2 & 34 & Total \\
\hline
\end{tabular}

Table 3: Palmer coefficient for microalgae species identified in different seasons in Sanandaj Dam Lake.

\begin{tabular}{|c|c|c|c|c|}
\hline Winter & Autumn & Summer & Spring & No. Station \\
\hline 11 & 18 & 15 & 11 & Station1 \\
\hline 21 & 13 & 14 & 10 & Station2 \\
\hline 14 & 3 & 11 & 7 & Station3 \\
\hline 8 & 6 & 1 & 10 & Station4 \\
\hline 10 & 9 & 14 & 10 & \\
\hline
\end{tabular}

Based on the contamination coefficient of Palmer, the number 0-10 indicates water without pollution and 10-15 medium pollution, 15-20 polluted and 20 and above indicate high pollution. At station 1, polluted water in autumn and in other samples the average load of algae pollution was moderate. In Station 2, the water was polluted only in winter, and in the rest of the samples, the pollution was moderate. The 3-point pollution station has been low in the two summer and fall seasons and has had no pollution load in the other two seasons. At Station 4, the lake's water was free of pollution in all seasons. At Station 5, water pollution was moderate in the summer, but in other seasons, the lake's water was free of pollution.

\section{Discussion}

Algae are the main producers of organic matter in aquatic environments and form an important part of the food chain of aquatic organisms and fish; so much of aquatic production is directly dependent on their existence. Algae also oxygenate the surrounding environment through photosynthesis and oxygen release and are conducive to aquatic life and are used as an indicator of water quality Anneville, et al. [2]. Some species thrive in high-water eutrophic waters, while others are very sensitive to chemical or organic waste. Excessive growth of algae can lead to problems in water resources and the use of surface water treatment such as flavor, odor, color, toxicity, smooth clogging, accumulation of biological sludge on facilities, corrosion of facilities, formation of trihalomethanes and interference. Dilute with other refining processes Istvánovics, et al. [8]. Due to the fact that the number of species fluctuations in the Sanandaj Dam Lake is limited throughout the year and the existing species do not alternate with each other in different seasons, and in each season almost the same species and in the whole period in each season between 25-18 species Only temperature changes (possibly temperature correlation) can make such differences Simon, et al. [9]. 
An important study in the study of different microalgae communities is the number of species observed at different times during the year. In the Sanandaj Dam Lake during the study period, the highest number of species observed in a season during the year. In the Sanandaj Dam Lake, during the period, the maximum number of species observed in a season during the year. In the Sanandaj Dam Lake, during the period, the maximum number of species observed in a season is related to the summer and autumn seasons, each of which was identified by 25 species. While in winter the minimum number of species was 18 . Also, the study of algae, microalgae (in Sanandaj Azad Dam) shows that the biodiversity index has been different in different seasons and by comparing the charts, in winter (1.24) and spring (1.19) with water pollution and rising Water turbidity reduces the biodiversity of microalgae, and in the summer, as temperatures rise, so does their biodiversity (1.58).

Therefore, the seasonal study of the species diversity of microalgae showed that in spring, summer, autumn and winter, 23, 25,25 and 18 species, respectively, and the Shannon index was 1.58 , $1.41,1.24$ and 1.19 was recorded with the highest species diversity as well as the Shannon Index for summer and autumn. Microalgae reported as clean water indicators include: Melosira, Cyclotella, and Dinobryon species, which have a significant population of Cyclotella Dinobryon species in this project, while Nitzchia palea, Microcystonasaea ahanugiongosa, Apcystonise aerugiongosa, Ap. The infected have not been identified in this study. The two species Microcystis aerugiongosa, Aphanizomenon flos-aquae, are related to toxic blooms and toxic states and anoxic states. They are associated with harmful blooms in polluted waters that produce odors and unpleasant odors. Due to their short life cycle, plankton reacts rapidly to environmental changes, which is why the abundance and composition of plankton species is significant in showing the water quality in which they are observed. Not only do they strongly influence certain non-biological aspects of water quality (such as $\mathrm{pH}$, color, odor, and taste), but in a scientific sense, they are part of water quality.

However, the validity or accuracy of plankton as an indicator of water quality may be limited due to their unstable nature and uncoordinated distribution. Of course, in the case of rivers, their origin can be unknown and the duration of their contact with pollutants is unknown. Is a transition Wan Maznah, et al. [7]. Based on the numbers obtained in this study, three cases of algae pollution were observed in stations 1 and 2 . The amount of algae contamination in winter has been. In other samples, the contamination was relatively low. And the conditions were suitable for aquaculture. Algae species are a major contaminant in improving rivers and lakes because they oxygenate the water while photosynthesizing and combine elliptical and non-elliptical materials in their cells, thus purifying water pollution. They are good for determining water quality Lobban, et al. [10]. In the study, the pollution index of station one showed that the highest rate of pollution index was 18 with medium pollution load and in station 2; the highest rate of pollution was in winter. In stations 3 and 4 , pollution was low, and in the end, station 1 had the highest level of pollution and station 4 had the lowest. But it should be noted that even a poisonous bloom can have a high risk potential. In general, due to the absence of harmful species and the presence of beneficial species, microalgae conditions are favorable for fishing in Sanandaj Dam Lake, but it should not be forgotten that in order to fish, it is necessary to monitor lake water monitoring [11-16].

\section{References}

1. Njiru M, Kazungu J, Ngugi C C, Gichuki J, Muhoozi L (2008) An overview of the current status of Lake Victoria fishery: Opportunities, challenges and management strategies. Lakes \& Reservoirs Research and Management 13(1): $1-12$

2. Anneville O, S Souissi, S Gammeter, D Straile (2004) Seasonal and interannual scales of variability in phytoplankton assemblages: comparison of phytoplankton dynamics in three peri-alpine lakes over a period of 28 years. Freshwater Biology 49(1): 98-115.

3. Rakaj M (2010) Biological water quality of Lake Shkodra based on the diatoms and cyanobacteria bioindicator species. BALWOIS-Ohrid Republic of Macedonia 25: 1-5.

4. Mirzajani A, Abbasi K, Makaremi M, Abedini A, Borani M, et al. (2012) Lymanology of Eligo-Mesotrof Lake Tahm in Zanjan Province. Iranian Journal of Biology 25(1): 74-89.

5. Moisan TA, Rufty KM, Moisan JR, Linkswiler MA (2017) Satellite Observations of Phytoplankton Functional Type Spatial Distributions, Phenology, Diversity, and Ecotones. Front Mar Sci 4: 189.

6. Richmond A (1994) Handbook of microalgal culture biotechnology and applied phycology. Blackwell publishing, USA, pp. 566.

7. Wan Maznah W O, Mansor M (2000) Periphytic Algal Composition in Pinang River Basin, A Case Study on One of the Most Polluted Rivers in Malaysia. Journal of Bioscience 1: 53-67.

8. Istvánovics V, L Somlyody, A Clement (2002) Cyanobacteria-mediated internal eutrophication in shallow Lake Balaton after load reduction. Water Research 36(13): 3314-3322.

9. Simon N, Cras A L, Foulon E, Lemée R (2009) Diversity and Evolution of Marine Phytoplankton. Comptes Rendus Biologies 332: 159-170.

10. Lobban CS, Chapman DJ, Kremer BP (1988) Experimental Phycology: A laboratory Manual. Press Syndicate. University of Cambridge, UK, p. 4755.

11.Palmer C M (1969) A composite rating of algae tolerating organic pollution. J Phycol 5(1): 78-82.

12. Newell GE, Newell KC (1977) Marin plankton. Hutchinson and Co London, UK, pp. 242.

13. Shannon CE, Weaver W (1963) The Mathematical Theory of Communication. University of Illinois Press, Urbana, pp.117.

14. (2005) APHA S. Standard Methods. American Public Health association. Washington DC, USA, pp. 346

15. Kromkamp J, Underwood G J C (1999) Primary production by phytoplankton and microphytobenthos in estuaries. Advances in Ecological Research 29: 93-153.

16.Žutinić P (2014) Phytoplankton as a biological predictor in assessment of the ecological status of karstic lakes (case study-NP Plitvice lakes). PhD Thesis, University of Zagreb, Zagreb. 
ISSN: 2574-1241

DOI: 10.26717/BJSTR.2021.35.005703

Fatemeh Sadat Tahami. Biomed J Sci \& Tech Res

(c) (P) This work is licensed under Creative BY Commons Attribution 4.0 License

Submission Link: https://biomedres.us/submit-manuscript.php

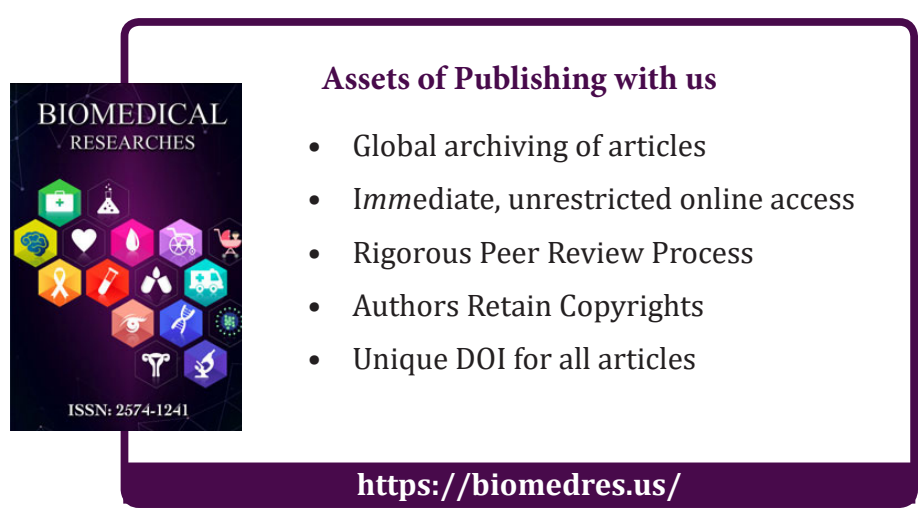

